\title{
Trabalhadores rurais diante da violência
}

\author{
Maria do Socorro de Abreu e Lima
}

\section{SciELO Books / SciELO Livros / SciELO Libros}

LIMA, MAS. Trabalhadores rurais diante da violência. In: OLIVEIRA, TB., org. Trabalho e trabalhadores no Nordeste: análises e perspectivas de pesquisas históricas em Alagoas, Pernambuco e Paraíba [online]. Campina Grande: EDUEPB, 2015, pp. 309-327. ISBN 978-85-7879-333-3. Available from SciELO Books $<$ http://books.scielo.org $>$.

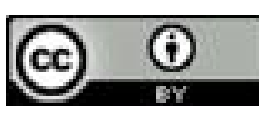

All the contents of this work, except where otherwise noted, is licensed under a Creative Commons Attribution 4.0 International license.

Todo o conteúdo deste trabalho, exceto quando houver ressalva, é publicado sob a licença Creative Commons Atribição 4.0.

Todo el contenido de esta obra, excepto donde se indique lo contrario, está bajo licencia de la licencia Creative Commons $\underline{\text { Reconocimento 4.0. }}$ 


\section{Trabalhadores rurais diante da violência}

Maria do Socorro de Abreu e Lima

A violência sempre esteve presente na história do Brasil, em que pesem as tentativas de se passar uma imagem de que o povo brasileiro tem índole pacífica, e é bom e ordeiro por natureza. Desde a chegada dos europeus, que se apossaram das terras e dizimaram a maioria das populaçóes nativas, as relaçóes sociais são marcadas pela violência. Isto aconteceu no sistema de plantation, com a riqueza sendo produzida por escravizados negros, fontes de lucro sob a forma de máo-de-obra e como objetos de compra e venda, mas também em diversas outras formas de uso da terra, em que os proprietários impunham-se aos pobres usando seu poder econômico, político e mesmo militar. A Igreja sedimentava essa dominação com um discurso que enaltecia a obediência e a humildade defendendo um modelo de colonizaçáo menos agressivo com os nativos, cuja mão-de-obra ela própria tinha interesse em explorar.

Diante desse quadro, os explorados posicionaram-se, muitas vezes, contra a opressão em que viviam. A resistência indígena e negra, atualmente melhor estudada, marcou toda a nossa história. Com a promulgação da Lei de Terras (1850) e a abolição da escravidáo (1888), da forma incompleta como foi feita as possibilidades de melhores condiçóes de vida e de trabalho para os trabalhadores do campo em nosso país continuaram cada vez mais distantes. Se iniciativas de contestação apareciam, como foi 
o caso memorável de Canudos, do Contestado, do Caldeirão, entre outros, a repressáo se fazia feroz.

Ao longo da primeira metade do Século XX, a proletarizaçáo dos trabalhadores do campo era geral em Pernambuco, particularmente na Zona da Mata sul. A maioria vivia em casas que pareciam antigas senzalas, sem direito a fazer lavoura. A Consolidação das Leis do Trabalho (CLT) não lhes foi especificamente concedida, embora lhes permitisse, em tese, por meio dos artigos 76 e 129 , o direito ao salário mínimo e a férias desde $1943^{1}$. E se ainda na segunda metade dos anos 1940, apareceram as Ligas Camponesas, lideradas pelo Partido Comunista do Brasil - PCB, elas foram perseguidas e fechadas a partir de 1947, quando se iniciou a Guerra Fria, e o PCB foi colocado novamente na ilegalidade. Foi a partir dos anos 1950 que os trabalhadores rurais passaram a se organizar de maneira mais significativa, para reagir contra a exploraçáo e a opressão em que viviam.

Em Pernambuco, esse movimento tornou-se marcante, com a fundação da Sociedade Agrícola dos Plantadores e Pecuaristas de Pernambuco (SAPPP), em 1954, cujas bases eram os pequenos proprietários que passaram a ter que enfrentar o dono da terra que pretendia expulsá-los das terras arrendadas. A repressão atribuiu o nome de Liga a essa organização, que ficou conhecida e assumida como Ligas Camponesas.

Com a desapropriação do Engenho Galileia, em 1959, essa organização tornou-se referência para todo o movimento camponês e assumiu, a partir de 1961, no Congresso de Belo Horizonte, a proposta de Reforma Agrária na Lei ou na Marra. Manuel Correia Andrade escreveu que, "em qualquer estado do Nordeste, mesmo onde [a Liga] não fora fundada, era comum um camponês injustiçado dizer para o capataz ou para o patrão: 'Graças a Jesus Cristo a Liga vai chegar. Será nossa liberdade'”2. Liberdade de ter direitos, de ser respeitado, de náo sofrer violência cotidianamente, como era o dia a dia da maioria dos trabalhadores rurais.

\footnotetext{
1 ANDRADE, Manuel Correia de. A terra e o homem no Nordeste. São Paulo: 2.ed., Brasiliense, 1964, p. 118.

2 Ibidem, p. 249.
} 
Violência que se expressava no excesso de trabalho, na possibilidade, sempre presente, de expulsão, de proibição do plantio ou da criação de pequenos animais. Violência nos preços cobrados pelo barracão, que implicava, muitas vezes, na formação de uma dívida impagável, que obrigava o trabalhador a fugir ou "vender-se" a outro patrão, que lhe adiantaria um pagamento para que pudesse saldar seu antigo débito. Violência no trato com as mulheres, particularmente contra as mais jovens e bonitas, assediadas e, não raras vezes, violentadas por proprietários ou seus prepostos. Violência, enfim, contra a própria vida, pois náo era incomum um camponês ser surrado por chupar um pedaço de cana, assassinado por se negar a fazer algum trabalho que considerava inadequado ou protestar contra alguma arbitrariedade ocorrida.

Refletindo sobre a violência contra os trabalhadores da cana, Christine Dabat lembra que "a imensa maioria dos casos estava associada a questóes de organizaçáo do trabalho e de remuneração (o que se constitui num fator econômico)", mas também "como um meio de dissuasão de lutar: 'os direitos eram perigosos"”.

No início dos anos 1960, organizaram-se os sindicatos rurais, que lutavam, fundamentalmente, pela implementação da legislação trabalhista no campo, o que só seria efetivado em novembro de 1963, a partir da grande greve dos canavieiros, que selou o Acordo do Campo, mediado pelo governador Miguel Arraes. Além do reajuste de $80 \%$ para todos os assalariados agrícolas, no prazo de 60 dias, os trabalhadores deveriam ter suas carteiras de trabalho assinadas, e as empresas fariam o desconto das contribuiçóes sindicais em folha. Porém, as lutas pela efetivação dessas conquistas foram levadas pelos assalariados agrícolas, que enfrentaram muita violência patronal. Dois casos foram marcantes, antes mesmo dessa greve: o primeiro ficou conhecido como o 'Massacre da Usina Estreliana', quando, em janeiro de 1963, cinco trabalhadores foram mortos e mais três feridos ao serem

DABAT, Christine Rufino. Moradores de engenho: relaçóes de trabalho e condiçóes de vida dos trabalhadores rurais na zona canavieira de Pernambuco segundo a literatura, a academia e os próprios atores sociais. Recife: Editora Universitária da UFPE, 2007, p. 668 e 673. 
recebidos a bala numa manifestaçáo devido ao não pagamento do $13^{\circ}$ salário. Em agosto de 1963, já no governo Arraes, houve o assassinato de uma liderança trotskista, Jeremias, que atuava em Serrinha, base do sindicato de Itambé, num episódio conhecido como o 'Massacre do Engenho Oriente', quando entre 500 e 1.000 trabalhadores foram reivindicar o pagamento atrasado do $13^{\circ}$ salário e foram vítimas de uma emboscada preparada pelo dono do engenho, a qual resultou em cerca de 13 feridos. Apesar de serem indiciados 21 suspeitos, ninguém foi preso. "O promotor foi ameaçado de morte" e "após o golpe civil-militar de 1964, tanto o promotor público como o oficial [designados para o caso] foram exonerados sob a acusação de 'subversão caluniosa"'4 Eles só seriam absolvidos em 1978.

Durante sua gestáo, o governador Miguel Arraes procurou tomar atitudes, no sentido de diminuir a violência no campo de Pernambuco, chegando a apreender armas em várias propriedades rurais, numa atitude bem ousada. E procurou garantir melhores condiçôes de trabalho para os policiais, para que eles pudessem ter mais autonomia diante dos donos de terras.

No período da ditadura, a violência atingiu amplos setores da população, sob a forma de negação de direitos, intervençóes em organizaçóes políticas e sindicais, censura, perseguiçóes, assassinatos, 'desaparecimentos', etc. No que diz respeito aos trabalhadores rurais, as arbitrariedades se intensificaram: muitos foram expulsos de suas terras ou de suas moradas sem nenhuma indenização, e suas necessidades foram ignoradas. Assassinatos vários. Para os grandes projetos vinham os benefícios, mantendo-se o processo de modernização conservadora. A propriedade da terra concentrou-se. Manteve-se o status quo.

A resistência no campo, contudo, foi constante. Este texto procura tratar de alguns desses conflitos ocorridos no estado de Pernambuco, particularmente após o golpe de 1964.

De imediato, a repressão generalizou-se. O caso de Gregório

4 GALLINDO, José Felipe Rangel. Trotskismo no campo: o Jeremias das caminhadas. Cadernos de História - Oficina da História: trabalhadores em sociedades açucareiras, ano 6 , n.6, 2010, p. 144. 
Bezerra, líder camponês e dirigente do $\mathrm{PCB}$, preso no município de Cortês, levado para Recife e, nas máos do Coronel Vilocq Viana, torturado em praça pública, chocou muitas pessoas. Também são chocantes os relatos de Paulo Cavalcanti5 sobre a quantidade de presos, particularmente aqueles vindos do campo, as condiçóes em que se deram essas prisões e as dificuldades enfrentadas por esses camponeses, que estavam distante de seus lugares de origem, onde podiam contar com mais solidariedade. Outro relato significativo foi feito pelo entâo presidente do sindicato rural de Palmares ligado aos comunistas:

Quando chegamos ao IV Exército, fui empurrado com força para dentro de uma sala, de maneira táo brutal que lasquei a testa numa quina da parede. $\mathrm{O}$ sangue correu em abundância. Fiquei todo vermelho de sangue (...) Naquela sala vi muita gente que estava presa. Vi Luiz Portela de Carvalho, ex-prefeito de Palmares. Ele estava de pé, de gravata, pois não tinha cadeira, nem banco para sentar; vi Leônidas, barraqueiro da Usina Caxangá, que participou de um movimento em favor dos camponeses naquela usina. (...) Já o Leônidas estava visivelmente aperriado. Ele tinha uns cabelos brancos e grandes, que por sinal serviam para os soldados pegarem pelos cabelos e baterem com a cabeça dele pelos cantos das paredes dizendo que ali era o lugar de todo mundo prestar contas do que fez

É ainda de José Eduardo o seguinte relato:

Meia-noite do terceiro dia, chegou um grupo de oficiais com uma lista e chamou também meu

5 CAVALCANTI, Paulo. Nos tempos de Prestes. Recife: Guararapes, 1982, p. 319.

6 José Eduardo de Lima Filho apud MENEZES, Paulo. Sindicalismo X repressáo. Recife: Nordestal, 1983, p.42. 
nome. Junto comigo, que me lembro, foram também Agrício Ferreira, Leônidas, que já falei nele, e Manoel Felix da Silva, secretário do Sindicato dos Trabalhadores Rurais de Palmares, que apanhou tanto na prisão até ficar rebentado. (...) Acompanhamos os oficiais com um certo pavor. De um lado nos contentávamos por não ter vindo com eles nenhum senhor de Engenho - daqueles que o Exército deu carteira para prender e fazer, pois, de vez em quando víamos sair da sala preso seguro por esses senhores de Engenho e voltavam torturados e espancados. Por outro lado nos colocaram em um carro e, em alta velocidade pela beira mar, as praias de Boa Viagem e Pina, sugeriam a nossa imaginação que eles iam nos jogar em alto mar. O temor corria na espinha. Nós éramos como carrego de cana que se levava aonde se quer. Nosso medo era que nos moessem pra tirar o caldo ${ }^{7}$.

Embora negado pelas autoridades militares, que, oficialmente, emitiam informes para seus subordinados, orientando-os no sentido de, entre outras coisas, "não permitir que civis efetuem prisóes; comunicar imediatamente quando estiver ocorrendo arbitrariedades pelos proprietários; não se colocar a serviço dos patróes, e sim manter-se a serviço do governo" 8 , temos, no testemunho de José Eduardo, como isso de fato se dava. Também vale ressaltar o temor e a ansiedade que tomavam conta dos presos diante da iminência da tortura e da possibilidade de um destino incerto, sabe-se lá, o pior destino.

É importante assinalar que, apesar de os militares terem tomado o poder sem que houvesse uma resistência efetiva, no campo, foi comum a ida de trabalhadores rurais para os seus sindicatos

7 Ibidem, p. 43.

8 Arquivo DOPS - PE, pasta 29.679. Serviço de Orientação Rural de Pernambuco - SORPE. (Arquivo Público Jordáo Emerenciano - Recife). 
em busca de armas para defender o governo constituído, em especial, nos sindicatos ligados aos comunistas assim como nas ligas camponesas. Para eles, era clara a relação entre a conquista de direitos, sua organização sindical e a participação política. Assim, dispunham-se a defender o governo, sobretudo o estadual, de Miguel Arraes. $\mathrm{O}$ fato de não existirem armas para organizar a defesa levou a que se dispersassem e, cada um do seu jeito, procurou se proteger ou fugir. Contudo, chegou a haver uma tentativa concreta de resistência em Vitória de Santo Antão, onde se situava a liga camponesa mais importante de Pernambuco: a professora e ativista das ligas, Maria Celeste Vidal, dirigiu-se à rádio local e, de microfone em punho, conclamava o povo a resistir ao golpe, até ser finalmente presa. Seu chamamento fez reunir muitos e muitos camponeses nas principais ruas da cidade.

O entâo presidente da Federação dos Trabalhadores na Agricultura, Manoel Gonçalo Ferreira renunciou ao seu cargo. Na época, ele era ligado à Igreja, mas também à organizaçáo de esquerda Açáo Popular (AP), e também presidia uma entidade unitária que estava se formando em Pernambuco e que congregava lideranças do Partido Comunista Brasileiro (PCB), da AP e da Igreja Católica. Segundo ele próprio, sua renúncia era necessária para evitar uma repressáo maior à Federação. Mesmo assim, ficou preso por 97 dias $^{9}$. José Eduardo, presidente do Sindicato de Palmares, conforme já dito, mas também secretário geral da nova Federação Unitária dos Trabalhadores Rurais, também ficou preso por cerca de três meses, tendo sofrido torturas em diferentes momentos no Regimento de Obuzes de Olinda.

A violência contra os trabalhadores rurais, então, tornou-se mais ampla, praticamente irrestrita, porque, agora, os proprietários tinham certeza da impunidade. As Ligas Camponesas foram fechadas, e a quase totalidade dos sindicatos rurais sofreu intervenção em Pernambuco. As forças de esquerda que tentaram atuar no campo foram duramente reprimidas, e os sindicatos passaram por uma fase de extrema legalidade, com muitos interventores 
ligados à Igreja, à Delegacia Regional do Trabalho ou mesmo diretamente aos proprietários rurais. Os partidos clandestinos que tentavam atuar no campo eram denunciados pelas diretorias sindicais. Estavam dadas as condiçóes para a implementação de um projeto de modernizaçáo conservadora, com os salários defasados, arrochados e as greves praticamente proibidas.

Mesmo agindo dentro da legalidade, a violência contra o movimento sindical continuou, assim como contra trabalhadores rurais que resistiam individualmente à opressão que se intensificava. Um dos casos bastante chocantes aconteceu em 1967, no município de Vicência, quando o delegado sindical, Manoel Tenório da Silva, foi assassinado pelo dono do Engenho Belmonte, e seu corpo, jogado no rio Natuba, na Paraíba. Nesse caso, o assassino chegou a ser preso, mas foi libertado posteriormente ${ }^{10}$.

Foram muitos os casos de expulsão de trabalhadores do campo para as chamadas pontas de rua sob diferentes formas. Aos proprietários não era mais interessante ter moradores em suas propriedades, pois eles deveriam, de acordo com a lei, ter carteira assinada e receber os direitos devidos, o que, geralmente, não era cumprido. Em casos extremos, os proprietários mandavam passar o trator sobre o sítio ou soltavam os animais para acabarem com a lavoura do morador. A Federação dos Trabalhadores na Agricultura do Estado de Pernambuco (FETAPE) entrava com muitas açóes na Justiça por conta disso, porém, nem sempre, conseguia resolver o caso a contento. Outro expediente muito usado na década de 1970 foi o de entregar as melhores terras para serem trabalhadas pelos não fichados, conhecidos como trabalhadores clandestinos, e o uso de outros expedientes que faziam o salário dos fichados decrescer ${ }^{11}$.

Episódio marcante da violência que imperava foi o chamado "Massacre de Matapiruma", ocorrido em 1972, no município de Escada. Setenta e dois empregados desse engenho haviam

10 Diário de Pernambuco, Recife, 28 jan. 1968, p. 9.

11 ABREU E LIMA, Maria do Socorro de. Construindo o sindicalismo rural: lutas, partidos, projetos. Recife: Editora Universitária da UFPE, 2012, p. 142. Para mais detalhes, consultar SIGAUD, Lígia. Os clandestinos e os direitos. São Paulo: Duas Cidades, 1979. 
ingressado com ações na Justiça do Trabalho reivindicando, entre outros direitos não cumpridos, o pagamento de férias e o $13^{\circ}$ salário. Apesar de vencerem em todas as instâncias, o senhor de engenho recusou-se a pagar o que devia. Nesse caso, foram agentes do Departamento de Ordem Política e Social - DOPS - que chegaram ao engenho e passaram a fuzilar os trabalhadores. "Cinco trabalhadores reagiram defendendo-se com foices e facóes, enquanto a maioria do grupo fugia. $\mathrm{O}$ conflito deixou dois mortos e vários feridos" ${ }^{\prime 2}$. Nesse caso, os mortos foram o lavrador José Inocêncio Barreto, um dos líderes do movimento, e o vigia do engenho, capanga do proprietário.

O caso foi abafado, mas o que consta nos arquivos do DOPS é que os camponeses estariam envolvidos em atividades subversivas. Ou seja, nesse massacre, foi o próprio Estado ditatorial que valeu-se diretamente da repressão a serviço dos interesses particulares de um senhor de engenho, indo contra a decisáo de outro órgão do Estado - a Justiça do Trabalho - acionada dentro da lei pelos reclamantes.

O Estado também foi o responsável direto pelo assassinato de outras lideranças do campo, como Amaro Luiz de Carvalho (1971), Manoel Aleixo da Silva (1973), Mariano Joaquim da Silva (1971) e Amaro Félix Pereira (desaparecido entre 1971 e 1972). O livro já citado, de Ana Carneiro e Marta Cioccari ${ }^{13}$, indica 56 trabalhadores rurais presos e/ou assassinados durante a ditadura no estado de Pernambuco, com base em fontes da FETAPE, da CONTAG ou do MST. Outra publicação indica 73 nomes, mais quatro não nomeados (um bebê, um agricultor, um lavrador e um trabalhador rural), como tendo sido assassinados em Pernambuco entre 1964 e $1986^{14}$. Essa publicação, que trata de todo o país, foi feita com base em informaçôes confirmadas, embora não inclua "os mortos pela seca e 'pela cerca' no nordeste (...) os envenenados por agrotóxicos, as crianças e adultos mortos

12 CARNEIRO, Ana; CIOCCARI, Marta. Retrato da repressáo política no campo - Brasil 1962-1985: Camponeses torturados, mortos e desaparecidos. Brasília: MDA, 2010, p. 46.

13 Ibidem.

14 MOVIMENTO DOS TRABALHADORES RURAIS SEM TERRA. Assassinatos no campo: crime e impunidade 1964-1986 (relatório). São Paulo: Global, 1987, p. 578-580. 
na lenta agonia dos acampamentos, os lavradores-garimpeiros soterrados sem que tivessem 'bamburrados', ou enterrados pela malária (...), os índios assassinados..." ${ }^{15}$. Ou seja, o número daqueles que sofreram violência no campo é muitas e muitas vezes maior do que se imagina.

Ainda no ano de 1979, ocorreu o caso da Fazenda Primavera, no município de Limoeiro, quando Moisés Dutra se apresentou dizendo que havia comprado a fazenda e querendo expulsar as quinze famílias que arrendavam a terra, algumas há mais de 40 anos. Soltou o gado, proibiu os rendeiros de fazerem benfeitorias e plantou capim. Os trabalhadores foram ao sindicato, arrancaram o capim e solicitaram à Delegacia Regional do Trabalho, assim como ao INCRA, a desapropriação da área. Entáo, o arrendatário André Lopes de Souza Filho foi baleado por um capanga do proprietário que, depois de ser vitimado, quase sofreu um atentado definitivo em pleno hospital:

(...) Na sexta-feira, 6 de julho, (Moisés) mandou 4 capangas no Hospital Oswaldo Cruz, em Recife. A missão dos capangas era matar André Lopes de Souza Filho. Dois capangas entraram pelos corredores do Hospital. Diziam que eram parentes de André. Que queriam doar sangue. Os outros dois foram pelo lado de fora. Forçaram a janela da enfermaria onde estava André. André conheceu que um dos capangas era irmão de Moisés. Os doentes alarmaram. Os capangas fugiram. O hospital tomou providências urgentes para proteger André. André já está noutro $\operatorname{lugar}^{16}$.

Esse relato ilustra a que ponto chegavam os proprietários para fazer valer seus interesses, sem levar em conta o que dizia a lei, como já foi visto no caso de Matapiruma. A edição de O Vagalume,

15 Ibidem, p. 18.

16 O Vagalume - Jornal da FETAPE, ano 1, n. 3, 1979, p. 15. 
jornal da FETAPE, prosseguiu a notícia falando sobre a função social da propriedade e fundamentando o direito dos camponeses com base no Estatuto da Terra, de novembro de 1964.

O mais comum, porém, era que os assassinatos acontecessem. Ainda em 1979, o número seguinte do jornal O Vagalume denunciava o assassinato de dois dirigentes sindicais, um deles presidente do sindicato de Serra Talhada, e o outro, militante do Sindicato de Santa Maria da Boa Vista. Em ambos os casos, estava em jogo a questão da terra.

A década de 1980 se iniciou com outra conjuntura. As lutas de massas foram sendo, aos poucos, retomadas a partir da segunda metade dos anos 1970 por diversos movimentos, como o popular, o estudantil, o de trabalhadores, o de mulheres e por anistia. Enfim, em que pese a continuidade do estado de exceção, uma gama muito grande de demandas e mobilizaçóes foi tomando as ruas e pressionando, de várias formas, o regime. $\mathrm{O}$ arrocho salarial era denunciado, e o movimento sindical enfrentava os patróes e a legislação de exceção com greves e protestos. Em Pernambuco, não foi diferente. Assim, em 1979, começaram as greves dos canavieiros que, mesmo feitas dentro das normas impostas pelo Ministério do Trabalho, mobilizaram toda a categoria de maneira intensa, apesar das ameaças e das perseguiçóes, contando com o apoio efetivo de muitos setores da sociedade.

Embora, ao longo dos anos 1980, as greves dos trabalhadores dos canaviais de Pernambuco tenham sido praticamente anuais (apenas em 1981 e 1985 elas não aconteceram) ${ }^{17}$, e as conquistas para os trabalhadores tenham sido importantes, muitas vezes, os acordos náo eram cumpridos pelo patronato, que sempre alegava grandes dificuldades no setor. E os trabalhadores enfrentavam situaçóes de intensa pressáo durante as mobilizaçóes e outros tipos de violência ao longo do ano, que iam desde as demissóes até a proibição da entrada de lideranças nos engenhos, inclusive dos próprios órgãos de fiscalização. Vigias e capangas permaneciam

17 ANDRADE, Sandra Maria Correia de. Açáo sindical no campo a partir da década de 70: o caso dos trabalhadores canavieiros de Pernambuco. São Paulo: Tese de Doutorado em Sociologia/Universidade de São Paulo, 1994. 
armados, e as violências física e psicológica eram permanentes.

Entre os sindicatos pioneiros dessa nova etapa de lutas, estavam os de São Lourenço da Mata e de Paudalho, na Mata norte. Nessa regiáo, concentrava-se, em meados da década, forte onda de violência, conforme denúncia da própria Federação dos Trabalhadores na Agricultura de Pernambuco:

Engenho Petribu I, município de Carpina: No dia 5 de fevereiro, espancamento do trabalhador Alcides e no dia 11 de fevereiro, agressão a cacete e a tiros do delegado sindical Francisco Inácio da Silva pelos novos 'vigias' do engenho. Engenho Carnaúbas, município de Paudalho: em 10 de janeiro de 1984, o trabalhador rural Antonio Rodrigues dos Santos, de 72 anos de idade e mais de 40 anos como morador do engenho depois de se recusar a deixar o sítio e a moradia foi assassinado a tiro por um dos vigias do engenho. Primeira versão da Secretaria de Segurança Pública veiculada em uma das rádios locais: crime passional. Versão final do inquérito policial: disparo acidental de arma de fogo.

Vale registrar que a vítima era sogro do presidente do Sindicato dos Trabalhadores Rurais de São Lourenço da Mata e tio do presidente do Sindicato dos Trabalhadores Rurais de Paudalho... ${ }^{18}$

Essa mesma entidade esclareceu o que chamou de "o lucrativo negócio da violência”, quando elencou, no mesmo documento, as vantagens do seu uso para os senhores de engenho e os usineiros que, ao expulsar os moradores, faziam-no sem o ônus da indenização por suas benfeitorias e do pagamento dos direitos trabalhistas. Quando sujeitavam os trabalhadores a uma carga de trabalho

18 FETAPE. Açúcar com gosto de sangue: violências na zona canavieira de Pernambuco. Recife: FETAPE, 1984, p. 14-15. 
ilegal (duplicando ou triplicando o tamanho das tarefas); quando procuravam impedir que eles reclamassem do roubo da balança e da falta de apontamento dos dias trabalhados; quando tentavam impedir reclamaçóes na Justiça do Trabalho e participação nos sindicatos; quando perseguiam, particularmente, delegados e líderes sindicais, tentando desarticular o movimento dos trabalhadores e, até, procurando impedir a ação de fiscalização pelos órgãos competentes, das atividades produtivas levadas, no caso, pelos canavieiros ${ }^{19}$.

Se essa questão é crucial na região voltada para a produção canavieira realizada com mão-de-obra assalariada, também o é, de modo geral, em todo o meio rural. $\mathrm{Na}$ regiáo de Surubim, no Agreste, ainda na década de 1970, ocorreram conflitos em algumas fazendas, com destaque para Tabu, pois os camponeses resistiram na terra de onde os proprietários queriam expulsá-los. $\mathrm{O}$ sindicato passou a ser dirigido por militantes do PCB, destacando-se nas lutas dos camponeses o advogado trabalhista Evandro Cavalcanti, que chegou a ser eleito vereador pelo PMDB. No início de 1987, Evandro Cavalcanti foi assassinado a mando dos proprietários, inconformados com as desapropriaçóes que estavam sendo feitas, fruto das lutas e da capacidade profissional e política do advogado. Seus matadores e agenciadores terminaram presos e condenados. Apesar de toda a pressáo feita desde entáo, os mandantes conseguiram fugir ${ }^{20}$.

Durante o governo Sarney, foi promulgado o Plano Nacional de Reforma Agrária em outubro de 1985. Sônia Lessa lembra que, embora o processo de concentração de terra no país seja causa da escalada da violência, ela "também encontra esteio em outros fatores, como as transformaçóes socioeconômicas e o comportamento do Poder Público" ${ }^{21}$. Ao colocar essa afirmação, a autora se refere à maneira como o Estado intervém no campo,

19 Ibidem, p. 1.

20 Entrevista concedida à autora por Jucilete Maria Gomes Cavalcanti (Leta), militante do PCB e do PMDB de Surubim e viúva de Evandro Cavalcanti, em 10 de outubro de 2002.

21 LESSA, Sônia. Violência no campo: o PNRA não é um instrumento da paz social. In: PESSOA, Dirceu (coord.). Política Fundiária no Nordeste: caminhos e descaminhos. Recife: FUNDAJ, Editora Massangana, 1990, p. 170. 
favorecendo, em diferentes aspectos, a grande propriedade, com políticas de isençóes, subsídios e apoios financeiros a projetos agrícolas privados. Com a modernizaçáo da agricultura, a terra é valorizada e torna-se objeto de especulaçáo, o que aumenta a ameaça de expulsáo para posseiros e pequenos proprietários, assim como para arrendatários, parceiros ou moradores.

O Estado é considerado pela autora, ao longo dos anos 1980, como incapaz de levar adiante uma política mais geral de combate à violência, não só em nível federal, mas também e particularmente, em nível estadual. Muitas vezes, "eles próprios são agentes dos conflitos" ${ }^{22}$, ou eles próprios coniventes ou omissos diante dessa situação. A impunidade é comum, e não existem medidas preventivas a esse respeito. Os proprietários e os seus prepostos andam e trabalham armados, os assalariados vivem sob a vigilância constante das armas. $\mathrm{O}$ isolamento do meio rural e a inexistência ou dificuldades de organizar os movimentos nessas regiôes são apontados, ainda, como fatores significativos para a manutenção do quadro de violência no campo, embora Sonia Lessa sinalize para outra leitura: "os fazendeiros, os grileiros, as empresas rurais e o próprio Estado, entre os que se valem da violência, estáo tendo dificuldades para manter sua dominação sobre a terra e os trabalhadores, sem o uso desse recurso" 23 .

O Estado também se colocou como fator de opressão e violência contra os trabalhadores rurais, nesse período, nos projetos de construção de barragens, no caso específico, na de Itaparica. Ao construir barragens e aumentar a produção de energia elétrica, como também ao implementar projetos de irrigaçáo e modernização agrícolas, dava infraestrutura e atraía os interesses de grandes grupos econômicos para a regiáo do Submédio Sáo Francisco. Era mais uma política modernizadora, com vistas a garantir um maior acúmulo de capital nas mãos da burguesia. Os trabalhadores, porém, não eram levados em conta pelo Estado, quando da elaboração dessas diretrizes nem quando da sua implementação. Assim sendo, foram necessárias muita organização e lutas

22 Ibidem, p. 171.

23 Ibidem, p. 172-173. 
várias, do final dos anos 1970 e por toda a década de 1980, cuja maior reivindicação era expressa na afirmação "Terra por Terra na margem do Lago" ${ }^{24}$. Em todo esse processo, que envolveu municípios de Pernambuco e da Bahia, houve desapropriaçóes e expulsôes de moradores, pagamentos irrisórios, sequestros, ameaças de morte e assassinatos. Como a obra era do Estado, muitas vezes, os trabalhadores eram intimados a tratar com advogados da Companhia Hidroelétrica do Sáo Francisco - CHESF - no quartel do Exército 25 .

Apesar da CHESF ter prometido concluir os projetos em 1988, os primeiros lotes irrigados só passaram a funcionar a partir de 1993. Como todo o processo foi muito lento, mesmo com várias conquistas, as famílias reassentadas enfrentaram uma situação de grandes dificuldades e desgaste.

Ainda vale lembrar que o início da década de 1980 foi marcado por uma enorme seca em todo o Nordeste. Ao lado do desespero devido à perda da lavoura ou do gado, o desemprego para os assalariados e a falta de trabalho para arrendatários, parceiros, posseiros e pequenos produtores em geral. Como a falta de água e a fome se acentuaram, o êxodo rural apareceu como a única saída para muitos. Coube ao Estado criar Frentes de Trabalho para fazer face à situação de extrema penúria enfrentada pelos trabalhadores sertanejos. Como costumava acontecer, os grandes fazendeiros viram, nessas horas, mais uma oportunidade para ampliar suas propriedades e fortalecer seu capital. Assim, frequentemente, o alistamento era feito com base em seus interesses e como moeda de troca. Havia casos de protestos e demissóes, acompanhadas, muitas vezes, da retenção do salário devido aos trabalhadores ${ }^{26}$.

As verbas eram destinadas, praticamente, a trabalhos nas grandes fazendas. Muitos trabalhadores eram obrigados a abandonar suas terras e vendê-las a preços irrisórios ou ficavam à mercê dos comerciantes, que lhes vendiam fiado a preços exorbitantes.

24 ARAÚJO, Maria Lia de. Na margem do lago: um estudo sobre sindicalismo rural. Recife: FUNDAJ-Massangana, 1990.

25 MOURA, Mariluce. As ilhas da resistência: os lavradores no vale do rio São Francisco. Goiânia: CPT, s/d, p. 32.

26 CONTAG. As lutas camponesas no Brasil. Rio de Janeiro: Marco Zero, 1981, p. 17. 
Mulheres não podiam participar das frentes de trabalho. Diante dessa situação, o movimento sindical procurou interferir. Em 1980, as entidades conseguiram garantir alguma participação, pois a responsabilidade das frentes de trabalho ficou com a Empresa de Assistência Técnica e Extensão Rural (EMATER), que procurou organizar um Plano de Emergência de tal modo que pudesse beneficiar os próprios trabalhadores, suas propriedades e suas famílias. Porém, 1982 era ano de eleição, e as frentes de emergência passaram a ser intermediadas pelas prefeituras. Foi no Nordeste que o PDS, partido da situaçáo, foi mais beneficiado. $\mathrm{O}$ que demonstra outra face da violência - a da compra do voto diante de uma necessidade inadiável. Uma violência permitida pelo Estado ainda ditatorial, embora travestido de democrático quando seguia o calendário eleitoral.

De toda essa situação nasceu algo positivo: em decorrência da impossibilidade de as mulheres se alistarem nas frentes de trabalho, começaram a protestar e a se organizar com vistas a essa conquista. E a partir de então, as mulheres trabalhadoras rurais de Pernambuco desencadearam um processo de atuaçáo no meio sindical e no meio rural que se intensificou cada vez mais, com maior participação e conquistas.

Ao tratar da violência no meio rural até o final dos anos 1980, tínhamos como objetivo demonstrar que, sob diferentes formas, ela se manteve ao longo dos anos, mesmo depois do fim oficial da ditadura e das intensas lutas levadas pelos trabalhadores rurais com apoio de tantas entidades e setores comprometidos da sociedade brasileira. Fruto da dominação de classe, da ação ou omissão do Estado, continua através das políticas que têm se colocado a favor dos grandes proprietários que hoje representam algo conhecido como o agronegócio, que comumente passam ao largo do respeito aos preceitos constitucionais da funçáo social da propriedade e náo levam em conta, efetivamente, uma política que considere a importância da preservação do meio ambiente e construção de uma sociedade menos desigual em nosso país.

Uma das questóes que chama à atenção é que a disputa pela terra e pelo cumprimento dos direitos dos trabalhadores rurais 
manteve-se constante, mesmo quando o regime não era mais ditatorial. Após a promulgação da Constituinte de 1988, ou seja, vivendo-se sob um regime dito democrático, continuaram os assassinatos a líderes durante as campanhas salariais ao longo dos anos 1990. Com a intensificação da luta pela terra e a criação do Movimento dos Trabalhadores Rurais Sem Terra - MST - e de outros menos conhecidos, mas voltados para os mesmos objetivos, tornou-se comum o uso da violência em processos de expulsão. No ano de 1997, no engenho Camarazal, em Nazaré da Mata, região norte do Estado, os trabalhadores que haviam ocupado o referido engenho foram surpreendidos à noite por um grupo de homens que chegaram atirando. $\mathrm{O}$ saldo foi dois trabalhadores assassinados e seis feridos, inclusive duas crianças ${ }^{27}$. Apesar de, no caso do sindicalismo rural, não serem mais tão comuns essas açóes truculentas durante as campanhas salariais, a pressão pelo aumento de produtividade e o uso de trabalho análogo à escravidão também passaram a acontecer em Pernambuco. A ideia de que a propriedade da terra deve ter uma função social, como assevera a lei, ainda parece bem distante dos proprietários e, frequentemente, do próprio Poder Judiciário.

\section{REFERÊNCIAS}

ABREU E LIMA, Maria do Socorro de. Construindo o sindicalismo rural: lutas, partidos, projetos. Recife: Ed. Universitária da UFPE, 2012.

ANDRADE, Manoel Correia de. A terra e o homem no Nordeste. 2. ed. São Paulo: Brasiliense, 1964.

ANDRADE, Sandra Maria Correia de. Açáo sindical no campo a partir da década de 70: o caso dos trabalhadores canavieiros de Pernambuco. Sáo Paulo: Tese de Doutorado em

27 MELO, Paula Reis. Discurso e recepçáo: o sujeito político na recepção das mensagens do MST. Recife: Dissertação de Mestrado em Administração Rural e Comunicação Rural/ Universidade Federal Rural de Pernambuco, 2000. 
Sociologia/Universidade de São Paulo, 1994.

ARAÚJO, Maria Lia de. Na margem do lago: um estudo sobre sindicalismo rural. Recife, FUNDAJ/Massangana, 1990.

CARNEIRO, Ana; CIOCCARI, Marta. Retrato da repressáo política no campo - Brasil 1962 -1985: Camponeses torturados, mortos e desaparecidos. Brasília: MDA, 2010.

CAVAlCANTI, PAUlO. Nos tempos de Prestes. Recife: Guararapes, 1982.

CONTAG. As lutas camponesas no Brasil. Rio de Janeiro: Marco Zero, 1981.

DABAT, Christine Rufino. Moradores de engenho: relaçóes de trabalho e condiçóes de vida dos trabalhadores rurais na zona canavieira de Pernambuco segundo a literatura, a academia e os próprios atores sociais. Recife: Ed. Universitária da UFPE, 2007.

GALLINDO, José Felipe Rangel. Trotskismo no campo: o Jeremias das caminhadas In Cadernos de História: oficina da história: trabalhadores em sociedades açucareiras. Departamento de História da UFPE - ano 6, n.6, 2009.

LESSA, Sonia. Violência no campo: o PNRA não é um instrumento da paz social. In: PESSOA, Dirceu (coord). Política Fundiária no Nordeste: caminhos e descaminhos. Recife: FUNDAJ/Massangana, 1990.

MELO, Paula Reis. Discurso e recepçáo: o sujeito político na recepção das mensagens do MST. Recife: Dissertação de Mestrado em Administração Rural e Comunicação Rural/Universidade Federal Rural de Pernambuco, 2000.

MENEZES, Paulo. Sindicalismo $\mathbf{X}$ repressáo. Recife: 
Nordestal, 1983.

MOURA, Mariluce. As ilhas da resistência: os lavradores no vale do Rio São Francisco. Goiânia: CPT, [s/d].

MOVIMENTO DOS TRABALHADORES RURAIS SEM TERRA. Assassinatos no campo: crime e impunidade 19641986 (relatório). São Paulo: Global, 1987.

SIGAUD, Lígia. Os clandestinos e os direitos. São Paulo: Duas Cidades, 1979.

\section{OUTRAS FONTES}

FETAPE. Açúcar com gosto de sangue: violências na zona canavieira de Pernambuco. Recife: FETAPE, 1984.

O Vagalume - jornal da FETAPE, Recife, n.3 e 4, 1979.

Jornal Diário de Pernambuco, Recife, 28 jan. 1968.

\section{ENTREVISTAS CONCEDIDAS À AUTORA}

- Jucilete Maria Gomes Cavalcanti (Leta). Militante do PCB e do PMDB de Surubim nos anos 80, viúva do advogado sindical Evandro Cavalcanti (10.out.2002). (Entrevista)

- Manoel Gonçalo Ferreira. Sindicato Rural de Panelas e primeiro presidente da FETAPE. Já falecido (29.abr.2002). (Entrevista) 